\section{Duty-Free Alcohol.}

A sHort time ago some letters on this subject appeared in NATURE, complaining of the difficulties experienced by scientific workers in obtaining permission to use such alcohol, and of the absurd regulations accompanying such permission. Perhaps the complainants, amongst whom, I remember, Sir William Ramsay was one, were somewhat unreasonable, for they should have considered that the officials in the Excise Department, as in other Government departments, are mostly of the "kings and captains" type; they really do not know what a laboratory or scientific work means; they certainly do not know what distillation implies, and probably their only idea as to alcohol is that it is something which is always either under- or over-proof, like the old lady's idea of stocks and shares, as being those things which go up and down in the City.

I was lucky enough to obtain permission to use duty-free alcohol, though only after long negotiations, and on the explicit assurance that I would not use it for running motor omnibuses round my laboratory. But recently the need for economy induced me to apply for permission to recover my waste spirit by distillation. After the usual six weeks' delay, and sheaves of official documents, an officer was sent to examine my stills, and was shown several shelves of retorts and flasks; but on my explaining to him that not more than one of these would be in use at the time for the purpose in question, we filled in the form of application for one still of about a litre capacity to be used in redistilling alcohol: and a permit for doing so eventually reached me. But in the course of the next few months the transaction had permeated to the domain of some higher official, whose eagle eye detected a flaw. Was I using a condenser in this distillation, and, if so, how many, and with what object? Again the official visited me, and was shown three condensers in a dusty corner of the lakoratory: so the form of application was altered accordingly; and I am now the proud possessor of full official permit, granted "as an indulgence," to use in my laboratory a still of not more than quarter-gallon capacity with three Liebig condensers. SPEnCer Pickering.

\section{Standards and Functions of Museums.}

"W. P. P." is in error in his article on the "Standards and Functions of Museums," which appeared in Nature for September 23, when he says that the Department of Public Health in the American Museum of Natural History answers to no more than one aspect of the Department of Economic Zoology of the British Museum of Natural History, that which concerns the organisms injurious to man.

The Department of Public Health does cover more than this; the exhibits so far arranged come under the following heads: water supply, sewage disposal, bacteria and bacterial diseases, insect-borne diseases, and military hygiene; while the exhibits in course of preparation deal with problems of diet. Especial stress naturally has been placed upon the bubonic plague, malaria, and yellow fever, as well as on the sanitation of the Panama Canal zone. Other aspects of the relations of insects to man are treated in the exhibits of the division of entomology, such as the importance of insects, benefits due to insects, and injuries caused by them. There is no collection of domesticated animals other than that illustrating variation under domestication, and, owing to lack of funds and space, no attempt can be made to bring together such a collection.

American Museum of Natural History, New York, October I9.
DR. LuCAS's brief summary of the ground covered by the Department of Public Health in the American Museum of Natural History is more complete than that which appeared in the forty-sixth annual report of the museum, which formed the subject of the article against which Dr. Lucas now lodges his protest; hence the "error" of the writer. We contend that only by a very elastic use of the term "Natural History Museum" can such subjects as the disposal of sewage, and water supply, be included. These are surely more fittingly themes for a Museum of Technology, while military hygiene and problems of diet would find a more suitable home in a Museum of Physiology. If these were omitted the funds and space which they absorb would be available for the collection of domesticated animals which Dr. Lucas is now obliged to neglect, to the great hurt of his museum.

$$
\text { W. P. P. }
$$

\section{Multiple-Character Evolution.}

ONE should have thought that a meeting of the Palæontological Society of America was scarcely a propitious occasion for promulgating as a newly discovered law that a body equals the sum of all its parts. As your reviewer has rightly remarked (NATURE, p. 286), it has been said before that every organism is made up of a great number of characters, each of which is in a state of flux. The obvious fact that any species has more than one differential character (of which we use only those which take our fancy) never had need of rediscovery, but it has occasionally been neglected, merely not thought of, sometimes with appalling consequences, as, for instance, it has been solemnly pleaded that if one character distinguishes a species, two should make a genus.

Zoological Laboratory, Cambridge, November 26.

\section{EGYPT AND THE FAR EAST. ${ }^{1}$}

PROF. ELLIOT SMITH has long established his position as our principal authority on the anatomical study of ancient Egyptian mummification. Before he undertook the systematic examination of mummies during the years he spent in Egypt, the vaguest and often the most erroneous notions were current with regard to the technical treatment of the corpse and its intestines by the ancient Egyptian embalmers. To the average Egyptologist such details necessarly appeared of a rather gruesome character, and, as a consequence, Prof. Elliot Smith, who brought expert medical knowledge to bear on an unrivalled collection of material, was able to obtain important results in what to all intents and purposes was a virgin field of research. His volume of the Cairo Catalogue, which was reviewed in NATURE on its publication, marked, as was pointed out at the time, a fitting culmination to his labours. When, therefore, its author has anything to tell us in connection with the subject he has made peculiarly his own, he is entitled to more than a respectful hearing. If on some essential

1 " On the Significance of the Geographical Distribution of the Practice of Mummification. A Study of the Migrations of Peol les and the Spreed of certain Customs and Beliefs." By Prof. G. Elliot Smith. From vol. lix., part ii , of Memoirs and Proceedings of the Manchester Literarv and Phllu1915.) Price 2s. $6 d$.

NO. 2405 , VOL. 96$]$ 